ФАЛЕНДИШ А.П., д.Т.н., професор,

СУМЦОВ А.Л., асистент,

АРТЕМЕНКО О.В., аспірант (Український державний університет залізничного транспорту)

\title{
Програмний комплекс вибору системи технічної експлуатації маневрового тепловозу
}

Розглянуто програмний комплекс вибору системи технічної експлуатації маневрових тепловозів. В основу комплексу покладено методику вибору системи технічної експлуатаџіï тягового рухомого складу на базі визначення комплексного коефіцієнту технічної експлуатації. Проведено розрахунки для вибору системи технічного обслуговування та ремонту для тепловозів ЧМЕЗ в залежності від основного типу роботи, щзо ними виконується.

Ключові слова: технічна експлуатація, маневровий тепловоз, комплексний коефіцієнт технічної експлуатацій, система ремонту.

\begin{abstract}
Вступ
Розвиток залізничного транспорту постійно вимагає підвищення ефективності функціонування його складових. Особливо це стосується локомотивного господарства, від якості роботи якого залежить ефективність роботи всієї галузі. Для цього необхідно проводити постійний пошук шляхів підвищення надійності рухомого складу та зменшення вартості перевезень. Можливість застосування різних варіантів систем технічного обслуговування та ремонту (ТОР) викликає необхідність їх порівняння для вибору оптимальної системи з урахуванням умов полігону експлуатації та конкретної серії тягового рухомого складу. Для цього використовують різні критерії, що характеризують лише окремі складові системи технічної експлуатації.
\end{abstract}

\footnotetext{
Аналіз літературних даних і постановка проблеми

Питанню визначення ефективної системи технічної експлуатації присвячено багато публікацій. Серед них одні 3 перших $є$ роботи Рахматуліна М.Д. та Четвергова В.А. Сутність методики, запропонованої М.Д. Рахматуліним [1], полягає у визначені ступеня завантаженості локомотивної енергетичної установки, який впливає на зношення іiї вузлів. Для оцінки цього параметру пропонувалося визначити співвідношення від завантаженості дизеля та питомою витратою палива. Таким чином були запропоновані диференційовані, міжремонтні пробіги, що залежать від умов роботи тепловозів в різних депо. Однак питання про економічну доцільність, тобто оптимальності міжремонтних пробігів, в даній роботі не розглядалося.

Дослідження під керівництвом Четвергова В.А. та Павловича Є.С. [2-4] сформулювали підхід до
}

визначення оптимальної структури системи ТОР на основі статистичних даних та закономірностей про надійність вузлів локомотива. В якості критерію оптимізації обрано коефіцієнт технічного використання або коефіцієнт ремонтоємності. При цьому не враховується економічна доцільність.

В роботі Бутько Т.В. [5] в якості критеріїв оптимальності окремих видів ТО та ПР прийняті мінімум питомих витрат на планові i непланові ремонти з урахуванням псування тепловозів на лінії. При такому підході не враховувалися особливості різних умов експлуатації.

Серед останніх праць по визначенню ефективної системи технічної експлуатації слід відмітити роботи Устенка О.В. [6] та Крашенініна О.С. [7]. В першій запропоновано визначення ефективності роботи технічної експлуатації проводити за коефіцієнтом готовності 3 врахуванням фактичної організації системи ремонту. В другій сформульовані основні напрямки та методика розрахунку збереження економічної та технічної доцільності продовження терміну експлуатації рухомого складу. В роботах $[8,9]$ проведено дослідження коефіцієнту технічного використання модернізованих тепловозів без вивчення його залежностей від системи утримання та експлуатаційних факторів. В публікаціях [10 - 12] розглянута надійність тепловозів в експлуатації та визначено коефіцієнт готовності для окремих серій i умов експлуатації.

Таким чином, в розглянутих роботах проведено суттєве дослідження 3 визначення системи технічного обслуговування та ремонту та спроби визначення оптимальної системи технічної експлуатації за окремими критеріями.

() А.П. Фалендиш, А.Л. Сумцов, О.В. Артеменко, 2016 
Вибір ефективної системи технічної експлуатації $є$ важливим та нагальною проблемою при експлуатації рухомого складу. Тому для іiі вирішення необхідно застосування комплексного підходу, тобто підходу, що враховує особливості всіх складових системи технічної експлуатації. Він дозволяє визначити ефективну систему, як з точки зору експлуатації, так і з погляду системи ремонту. При використанні такого підходу необхідно запровадити комплексний критерій оцінки. В якості такого критерію приймемо комплексний коефіцієнт технічної експлуатації.

Мета дослідження полягає у визначені комплексного коефіцієнту технічної експлуатації на прикладі тепловозів ЧМЕЗ за допомогою розробленого програмного комплексу.

\section{Основний матеріал дослідження}

Для характеристики експлуатаційної та ремонтної роботи локомотивного господарства i його структурних підрозділів, а також для оцінки використання тягового рухомого складу, визначення потреби в матеріальних, грошових та трудових ресурсах, визначення тягового рухомого складу, що експлуатується, використовують систему показників, яка складається 3 обсягових (кількісних) та якісних показників. В сукупності вони складають множину показників $P_{\mathrm{TE}}$, що в повній мірі характеризує ефективність прийнятої системи технічної експлуатації

$$
P_{\text {TE }}=\left\{M_{\text {експл }}^{\text {якіс }}, M_{\text {експл }}^{\text {кільк }}, M_{\text {тоР }}^{\text {якісн }}, M_{\text {тОР }}^{\text {кільк }}\right\}
$$

де $P_{T E}$ - загальна множина параметрів технічної експлуатації;

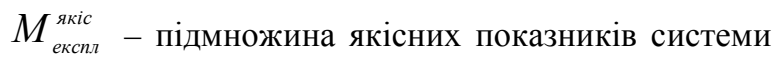
експлуатації локомотива;

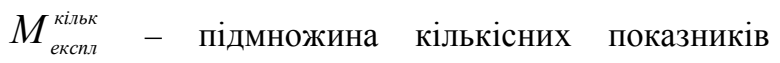
системи експлуатації локомотива;

$$
M_{\text {тоР }}^{\text {якін }} \text { - підмножина якісних показників системи }
$$
технічного обслуговування та ремонту локомотива;

$$
M_{\text {тоР }}^{\text {кільк }} \text { - підмножина кількісних показників }
$$
системи технічного обслуговування та ремонту локомотива.

Кожна $з$ цих підмножин масивів відображає лише окрему частину складної системи технічної експлуатації маневрових тепловозів в умовах залізниць України. Проведений аналіз фактичної системи експлуатації [13] та показників її оцінки [14] виявив доцільність запровадження нового критерію оцінки системи технічної експлуатації маневрових тепловозів. В основу його розробки була покладена концепція комплексного підходу в оцінці системи технічної експлуатації. Для цього із загального масиву показників було обрано сім, які найбільш повно характеризують технічну експлуатацію маневрового локомотива. Це сумарна вартість експлуатації локомотива, середня вартість проведення непланових ремонтів, обсяг виконаної роботи, тривалість непланового ремонту, дійсний фонд часу роботи локомотива, тривалість життєвого циклу та коефіцієнт технічного використання. Визначення комплексного коефіцієнту технічної експлуатації будемо проводити за формулою

$K_{K T E}=\frac{C_{E} T_{\partial}+C_{H P} T_{H P}}{Q T_{Ж Ц} K_{T И}}$

де $K_{K T E} \quad$ - комплексний $\quad$ коефіцієнт $\quad$ технічної експлуатації;

$Q$ - об'єм виконаної роботи;

$T_{\text {жц }}$ - тривалість життєвого циклу (прогнозований термін служби),

$K_{T И}$ - коефіцієнт технічного використання;

$C_{E}$ - витрати на систему технічної експлуатації протягом життєвого циклу;

$T_{\partial}$ - дійсний фонд часу експлуатації тепловоза;

$C_{H P}$ - середня вартість непланового ремонту;

$T_{H P}$ - середня тривалість непланового ремонту (тривалість відновлення).

Запропонований комплексний коефіцієнт враховує фактори системи експлуатації (об'єм виконаної роботи, вартість експлуатації) та показники системи ТОР (коефіцієнт технічного використання, вартість відновлення, час відновлення).

Серед показників що входять до комплексного коефіцієнту технічної експлуатації необхідне уточнення обсягу роботи, що виконується тепловозом. Для різних видів робіт на магістральному транспорті використовують різні вимірники виконаної роботи. Так для поїзної та вивізної роботи використовують тонно кілометро брутто, а для маневрової локомотиво-години. Обидва ці показники не враховують складності умов експлуатації тепловоза у повній мірі: особливості полігону експлуатації, вантажу що переміщується та ін. Тому в якості вимірника обсягу виконаної роботи, для тепловозів 3 електричною передачею потужності, найбільш доцільним є застосування сумарної електричної енергії виробленої дизель-генератором локомотива. Якщо при модернізації на тепловоз, 3 електричною передачею потужності встановлюють прилад обліку виробленої електричної енергії, тоді його розрахунок зводиться до простого фіксування фактичного значення. Застосування саме цього показника дозволяє враховувати при визначенні оптимальної системи 
технічної експлуатації різні види експлуатаційної роботи.

Вибір системи ТОР у відповідності з системою експлуатації вимагає визначення найбільш раціональної системи за комплексним коефіцієнтом технічної експлуатації шляхом проведення моделювання. Для цього скористаємося наступними вихідними даними: реальними варіантами системи ТОР та системи експлуатації. Згідно «Положенням про планово-попереджувальну систему ремонту технічного обслуговування тягового рухомого складу (електровозів, тепловозів, електро- та дизель-поїздів)» [15] для тепловозів серії ЧМЕ3 встановлені різні норми постановки на планові види ТО, ПР та КР в залежності від терміну експлуатації:

- при експлуатації в понад нормативний термін служби (1 стратегія);

- в межах нормативного терміну служби (2 стратегія);

- після глибокої модернізації новим силовим обладнанням (3 стратегія).

Окрім приведених норм проведемо дослідження системи технічної експлуатації модернізованого тепловозу серії ЧМЕ3 з дизелем Cat-3508 згідно 3 рекомендованими виробником нормами пробігу [16], ці норми розглянемо як 4 стратегію. Міжремонтні інтервали для всіх прийнятих стратегій наведені в табл. 1.

Обсяги робіт планових ТО та ПР і відповідно норми простою на них для всіх стратегій приймемо однаковими. Вони складають: для ТО-2 - 1,5 год., ТО-3 - 12 год., ПР-1 - 24 год., ПР-2 - 96 год., ПР-3 120 год.

Вибір системи ТОР необхідно проводити у відповідності з умовами експлуатації локомотива. Як показало дослідження [13] маневрові тепловози мають дуже широкий спектр використання, але найбільш характерними видами робіт $\epsilon$ маневрова, вивізна та вантажна. Тому доцільно вибір системи ТОР робити у відповідності $з$ основним типом роботи, на якому використовується локомотив.

Таблиця 1

\begin{tabular}{|c|c|c|c|c|c|c|c|}
\hline \multicolumn{8}{|c|}{ Міжремонтні інтервали для різних видів ТО, ПР та КР } \\
\hline \multirow{3}{*}{\begin{tabular}{|l|} 
№ \\
$\Pi / \Pi$
\end{tabular}} & \multirow{3}{*}{$\begin{array}{c}\text { Система } \\
\text { ТОР }\end{array}$} & \multicolumn{6}{|c|}{ Періодичність } \\
\hline & & ஸ́ & $\hat{0}$ & $\overrightarrow{\hat{E}^{\prime}}$ & $\begin{array}{l}m \\
\hat{E}\end{array}$ & ב' & $\begin{array}{l}2 \\
1 \\
1\end{array}$ \\
\hline & & діб & діб & міс & Mic & років & років \\
\hline 1 & 1 стратегія & 3 & 36 & 8,5 & 30 & 8,5 & 17 \\
\hline 2 & 2 стратегія & 3 & 45 & 8,5 & 30 & 8,5 & 17 \\
\hline 3 & 3 стратегія & 3 & 58 & 11 & 39 & 11 & 22 \\
\hline 4 & 4 стратегія & 5 & 60 & 12 & 36 & 7,5 & 15 \\
\hline
\end{tabular}

Для проведення моделювання режими роботи дизель-генераторної установки тепловоза встановимо відповідно до ВНД 32.0.06.001-99. Режими завантаження встановлені для маневрової та вивізної роботи. Нормативні значення наведені в табл. 2.

Таблиця 2

\section{Відносний час завантаження дизеля} на різних видах роботи

\begin{tabular}{|c|c|c|c|c|c|c|}
\hline \multirow{2}{*}{$\begin{array}{c}\text { № } \\
\Pi / \Pi\end{array}$} & \multirow{2}{*}{$\begin{array}{c}\text { Вид роботи, на якій } \\
\text { експлуатується } \\
\text { тепловоз } \\
\end{array}$} & \multicolumn{5}{|c|}{ Ступінь завантаження дизеля } \\
\hline & & $\begin{array}{c}\text { Холостий } \\
\text { хід } \\
\end{array}$ & $25 \%$ & $50 \%$ & $75 \%$ & 100 \\
\hline 1 & Mar & 6 & 40 & 12 & 1,5 & 1,5 \\
\hline 2 & Вивізна & 67 & 2 & 3 & 3 & 25 \\
\hline
\end{tabular}

Виходячи зі ступеня завантаження дизеля можемо визначити об'єм виконаної роботи. Він дорівнює сумі добутку потужності помноженої на час роботи на відповідному ступені завантаженості дизеля, тобто

$Q=\sum_{i=1}^{5} P_{i} t \tau_{i} / 100$

де $P_{i}$ - потужність на відповідному режимі, кВт;

$t$ - час роботи тепловоза, год;

$\tau_{i}$ - відсоток відносного часу завантаження дизеля на відповідному режимі, $\%$.

Витрати на систему технічної експлуатації, грн

$C_{T E}=C_{E K}+C_{T O P}$

де $C_{E K}$ - витрати на систему експлуатації локомотива, грн.;

$C_{T O P}-$ витрати на систему ТОР, грн.

Витрати на систему експлуатації складаються 3 витрат на експлуатаційні матеріали $C_{e \kappa}$ мат та витрат на локомотивну бригаду $C_{\text {л.б. }}$ Для маневрового тепловоза витрати на експлуатаційні матеріали складаються з витрат на паливо, дизельне мастило та витрат на інші мастильні матеріали. Витрати на окремий вид експлуатаційних матеріалів визначаються як об'єм спожитого матеріалу помножений на вартість матеріалу за одиницю об'єму. Тоді витрати на систему експлуатації $C_{E}$ (грн.) запишуться

$C_{E}=\sum_{y=1}^{n} q_{y} c_{y}+C_{\text {л.б. }}$, 
де $q y$ - витрата експлуатаційного матеріалу виражена в натуральних одиницях;

$c_{y}$ - вартість відповідного експлуатаційного матеріалу за натуральну одиницю, грн.;

$y$ - вид експлуатаційного матеріалу;

$C_{л . б}-$ витрати на локомотивну бригаду.

В загальному випадку при експлуатації тепловозів використовують наступні експлуатаційні матеріали: дизельне паливо, дизельне мастило, охолоджуюча рідина, компресорне мастило, пісок. Витрати експлуатаційних матеріалів безпосередньо залежуть від умов експлуатації.

Витрату палива визначаємо, враховуючи питому витрату та час роботи на відповідному режимі дизеля. Виходячи з цього, отримуємо

$$
\mathrm{G}_{\text {nал }}=\sum_{i=1}^{5} P_{i} t g_{i} \tau_{i} / 100
$$

де $g_{i}$ - питома витрата палива на відповідному режимі, кг / кВт • год.

Витрату дизельного мастила визначаємо як частку від витрати палива, тобто

$$
\mathrm{G}_{\text {мас }}=\mathrm{G}_{\text {пал }} \cdot \mathrm{g}_{\text {мас }} / 100
$$

де $\mathrm{g}_{\text {мас }}$ - питома витрата мастила на відповідному режимі, \%.

Витрати на інші експлуатаційні матеріали включено у вартість ТО та ПР.

Витрати на локомотивну бригаду приймемо згідно зі статистичними даними на рівні 32,5 грн/год.

Витрати на систему технічного обслуговування та ремонту складають

$C_{T O P}=\sum_{j=1}^{n} m_{j} C_{j}$

де $m_{j}$ - кількість відповідного виду ТО чи ПР,

$C_{j}$ - витрати на проведення відповідного виду ТО чи ПР, грн.

При проведені ТО та ПР на інших локомотивних депо витрати на проведення будуть складатися 3 вартості виду ТОР, витрат на пересилку до місця проведення та в зворотному напрямку. Тобто

$$
C_{T O}=\bigsqcup_{T O}+\bigsqcup_{\text {транс },}
$$

де $\bigsqcup_{T O}$ - собівартість ремонту, грн.; $\bigsqcup_{\text {транс }}$ - вартість транспортування, грн. KP.

Аналогічно визначаються витрати на проведення

Витрати на проведення відповідного виду ТО чи ПР при проведені їх безпосередньо в депо експлуатації будуть складати лише собівартість ТО або ПР. Їх можна визначити за [14].

3 точки зору надійності використовують два комплексні показники: коефіцієнт технічного використання та коефіцієнт готовності. Формулювання та визначення даних понять наведено у ДСТУ 2860 «Надійність техніки. Терміни та визначення». Згідно 3 цим стандартом коефіцієнт технічного використання $K_{m u}$ - це відношення математичного сподівання сумарного часу перебування об'єкта у працездатному стані за деякий період експлуатації до математичного сподівання сумарного часу перебування об'єкта в працездатному стані та у простоях, зумовлених технічним, обслуговуванням і ремонтом за той самий період.

Коефіцієнт готовності $K_{2}$ - імовірність того, що об'єкт виявиться працездатним у довільний момент часу, крім запланованих періодів, протягом яких використання об'єкта за призначенням не передбачено.

Згідно ДСТУ 2862 їх визначають наступним чином:

$K_{\text {ти }}=\frac{K_{\Gamma} T_{\text {д }}}{T_{\text {HОм }}}$,

$K_{\Gamma}=\frac{T_{O}(t)}{T_{O}(t)+T_{B}(t)}$,

де $T_{\partial}-$ дійсний фонд часу, год;

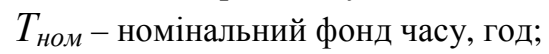

$T_{o}(t)$ - середній наробіток між відмовами, год;

$T_{b}(t)$ - середній час усунення відмов, год.

Дійсний фонд часу $T_{\partial}$ дорівнює номінальному фонду часу за винятком простоїв на планові технічні обслуговування та ремонти $t_{T O P}$, тобто

$T_{\text {д }}=T_{H O M}-T_{T O P}$

Час простоїв, пов'язаних з проведенням планових технічних обслуговувань (ТО), поточних ремонтів (ПР) та капітальних ремонтів (КР) $t_{T O P}$, визначається як сумарний час знаходження локомотива в окремому виді технічного обслуговування та ремонту, помножений на кількість ТО, ПР, КР протягом розрахункового періоду, тобто 
$T_{T O P}=\sum_{i=1}^{H} M_{T O P i} t_{T O P i}$,

де $M_{T O P i}$ - кількість ТО, ПР, КР $i$-го виду за період $t_{\text {ном }}$;

$t_{T O P i}$ - тривалість $i$-го виду ТО, ПР, КР, год;

$H$ - кількість видів ТО, ПР, КР.

При розрахунку $M_{T O i}$ та $T_{T O i}$ враховують всі планові види ТО та ПР, а також неплановий ремонт. При цьому не враховують проведення ТО-1.

Таким чином для розрахунку коефіцієнту технічного використання та визначення вартості системи ТОР необхідне визначення кількості проведених ТО та ПР. Для визначення цієї величини скористаємося методикою [17] 3 врахуванням величини наробітку і норми постановки на планові ТО та ПР у годинах роботи. Таким чином отримаємо наступні вирази:

$$
\begin{aligned}
& \mathrm{M}_{\mathrm{KP}}=\frac{\mathrm{t}}{\mathrm{T}_{\mathrm{KP}}} ; \\
& \mathrm{M}_{\Pi \mathrm{P} 3}=\frac{\mathrm{t}}{\mathrm{T}_{\Pi \mathrm{3} 3}}-\mathrm{M}_{\mathrm{KP}} \\
& \mathrm{M}_{\Pi \mathrm{T} 2}=\frac{\mathrm{t}}{\mathrm{T}_{\Pi \mathrm{2} 2}}-\mathrm{M}_{\mathrm{KP}}-\mathrm{M}_{\Pi \mathrm{\Gamma} 3} \text {; } \\
& \mathrm{M}_{\Pi \mathrm{P} 1}=\frac{\mathrm{t}}{\mathrm{T}_{\Pi \mathrm{P} 1}}-\mathrm{M}_{\mathrm{KР}}-\mathrm{M}_{\Pi \mathrm{P} 3}-\mathrm{M}_{\Pi \mathrm{\Gamma P} 2} ; \\
& \mathrm{M}_{\mathrm{TO} 3}=\frac{\mathrm{t}}{\mathrm{T}_{\mathrm{TO} 3}}-\mathrm{M}_{\mathrm{KP}}-\mathrm{M}_{\Pi \mathrm{C} 3}-\mathrm{M}_{\Pi \mathrm{CP} 2}-\mathrm{M}_{\Pi \mathrm{P} 1} \text {; } \\
& \mathrm{M}_{\mathrm{TO} 2}=\frac{\mathrm{t}}{\mathrm{T}_{\mathrm{TO} 2}}-\mathrm{M}_{\mathrm{KP}}-\mathrm{M}_{\Pi \mathrm{P} 3}-\mathrm{M}_{\Pi \mathrm{P} 2}-\mathrm{M}_{\Pi \mathrm{CP}}-\mathrm{M}_{\mathrm{TO} 3} \text {; }
\end{aligned}
$$

де $\mathrm{M}_{\mathrm{КР}}, \mathrm{M}_{\Pi Р 3}, \mathrm{M}_{\Pi Р 2}, \mathrm{M}_{\Pi Р 1}, \mathrm{M}_{\mathrm{TO} 3}, \mathrm{M}_{\mathrm{TO} 2}$ - кількість відповідно КР, ПР-3, ПР-2, ПР-1, ТО-3 та ТО-2;

$\mathrm{t}$ - час роботи локомотива на момент розрахунку, год.;

$\mathrm{T}_{\text {КР}}, \mathrm{T}_{\Pi Р 3}, \mathrm{~T}_{П Р 2}, \mathrm{~T}_{\text {ПР } 1}, \mathrm{~T}_{\mathrm{TO} 3}, \mathrm{~T}_{\mathrm{TO} 2}-$ норма міжремонтного інтервалу відповідно для КР, ПР-3, ПР-2, ПР-1, ТО-3 та ТО-2.

Враховуючи вирази (4 - 19), сумарні витрати на систему технічної експлуатації будуть зростати наростаючим підсумком з майже лінійною залежністю та стрибками - при проведені КР. Результат розрахунку витрат на систему технічної експлуатації приведено на рис. 1. 3 нього наочно видно, що витрати на різних системах майже не відрізняються.

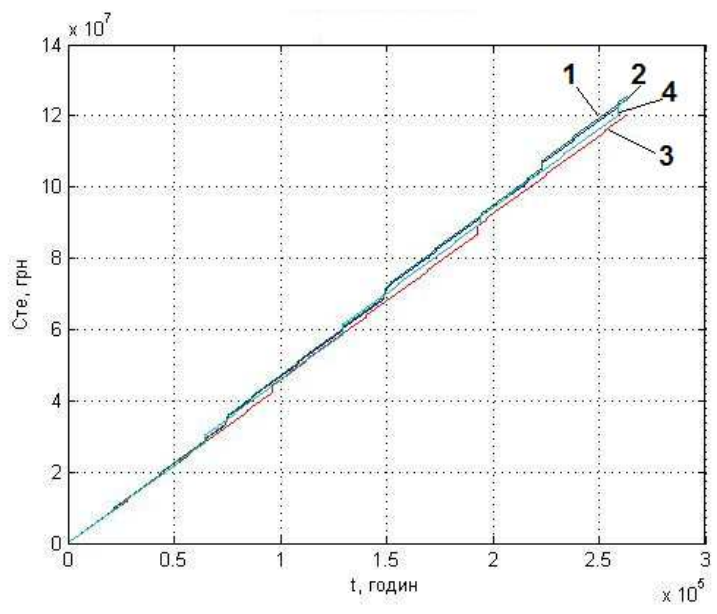

Рис. 1. Сумарні витрати на технічну експлуатацію маневрового тепловозу: $1 \div 4$ - відповідні номера стратегій

Виходячи 3 наведеної методики найбільш ефективною буде система при застосуванні якої буде найменший коефіцієнт $K_{K T E}$. Таким чином ми отримуємо модель визначення оптимальної системи ТОР при заданій системі експлуатації. Цільова функція в цьому випадку матиме наступний вигляд:

$K_{K T E}(t) \Rightarrow \min$

При цьому необхідне застосування обмежень

$\left\{\begin{array}{l}0<t<T_{ж и} \\ C_{н р}<C_{e} \\ T_{H Р}<T_{д} \\ Q>0\end{array}\right.$

Розроблена модель вимагає трудомістких та циклічних розрахунків. Тому доцільно іiі реалізувати у вигляді програмного комплексу алгоритм якого наведений на рис. 2. В ході виконання роботи програмний комплекс було розроблено за допомогою пакету прикладних програм для числового аналізу MATLAB.

За допомогою розробленого програмного комплексу було проведено розрахунки для двох систем експлуатації та чотирьох систем ТОР. Результати розрахунку наведені на рис. 3 та 4. 


\section{Початок}

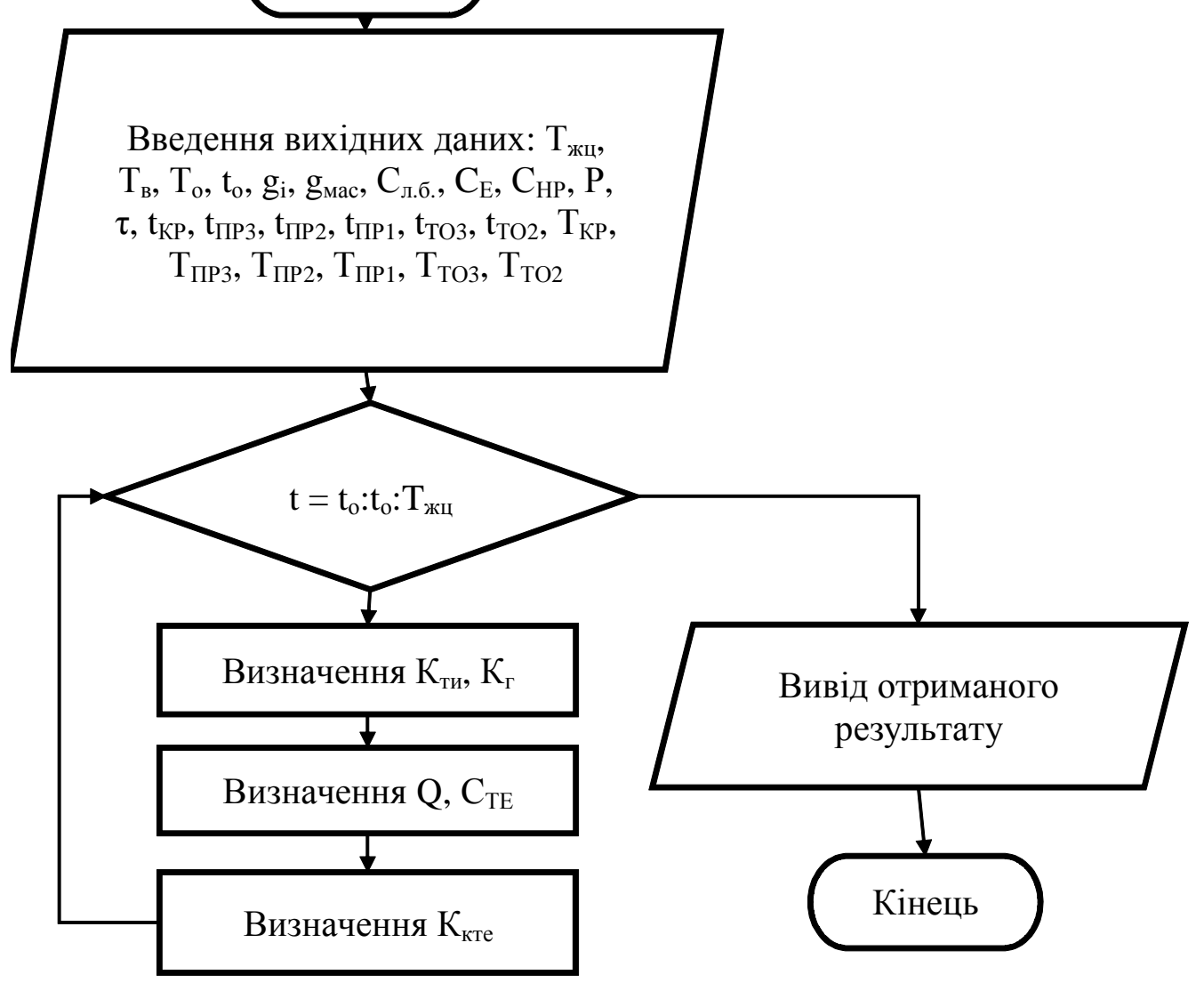

Рис. 2. Алгоритм програмного комплексу

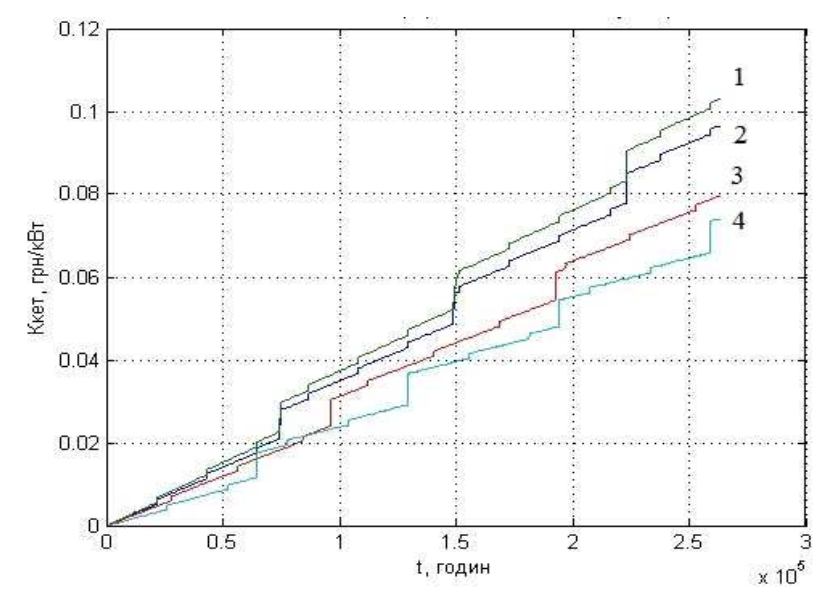

Рис. 3. Зміна комплексного коефіцієнту технічної

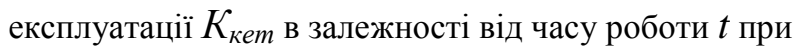
експлуатації на маневровій роботі: $1 \div 4$ - відповідні номера стратегій

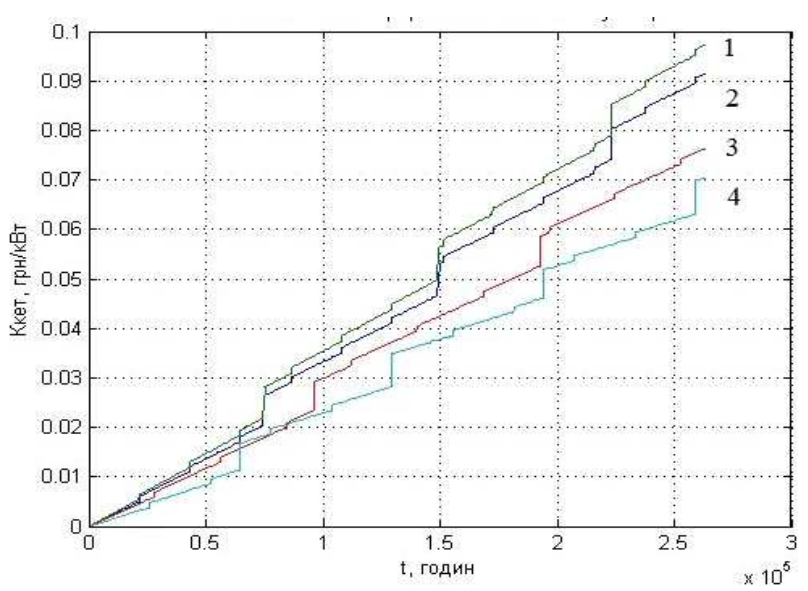

Рис. 4. Зміна комплексного коефіцієнту технічної

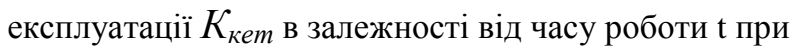
експлуатації на вивізній роботі: $1 \div 4$ - відповідні номера стратегій 
В результаті моделювання отримаємо зміну коефіцієнту 3 постійним зростанням протягом життєвого циклу. 3 рисунків наочно видно, що різка зміна комплексного коефіцієнту технічної експлуатації припадає на час проведення капітальних ремонтів, що пов'язано 3 відносно значними витратами на капітальний ремонт та великим часом простою на ньому.

\section{Висновки}

1 Запропонований комплексний коефіцієнт технічної експлуатації дозволяє провести оцінку різних варіантів комбінації система експлуатації - система технічного обслуговування і ремонту. Завдяки цьому виникає можливість підвищення ефективності застосування кожної наявної одиниці рухомого складу протягом усього життєвого циклу.

2 Розроблена методика визначення комплексного коефіцієнту технічної експлуатації дозволяє враховувати всі особливості як полігону експлуатації так і прийняту системи технічної експлуатації.

3 Створений програмний комплекс дозволяє значно скоротити витрати часу та трудомісткість визначення комплексного коефіцієнту технічної експлуатації.

4 Розрахунок комплексного коефіцієнту технічної експлуатації для модернізованих маневрових тепловозів серії ЧМЕ3 довів, що найбільш доцільною $є$ четверта стратегія технічного обслуговування та ремонту для всіх варіантів систем експлуатації.

\section{Література}

1 Рахматулин М.Д. Методы определения сроков межремонтной работы тепловозов. [Текст] / М.Д. Рахматулин. - Тр. МИИТ, 1960. - Вып.130. с. $147-149$.

2 Четвергов В.А., Пузанков А.Д. Надежность локомотивов. [Текст] / В.А. Четвергов, А.Д. Пузанков. - М.: Маршрут, 2003. - 415 с.

3 Павлович Е.С., Серегин Д.А., Четвергов В.А. Определение оптимальных пробегов тепловозов между ремонтами // Науч. тр. ОмИИТ, 1968. т. 87, Ч. 1. -102 c.

4 Галкин В.Г., Парамзин В.Н., Четвергов В.А. Надежность тягового подвижного состава - М: Транспорт, 1981. - 184 с.

5 Бутько Т.В. Совершенствование методов расчета параметров системы технического содержания локомотивов [Текст] : автореф. дис. на соиск. учен. степ. д-ра техн. наук : 05.22.07 / Т.В. Бутько. Харьков, 1996. - 47 с.

6 Устенко О.В. Основи формування віртуальної системи управління технічною експлуатацією локомотивів: дис. д-ра техн. наук: 05.22.07 / О.В. Устенко/ Укр. держ. акад. залізн. трансп. - Х., 2011. - 343 c.
7 Крашенінін О.С. Розвиток наукових основ визначення системи утримання локомотивів при подовженні терміну експлуатації понад нормативний: дис. д-ра техн. наук: 05.22.07 / О.С. Крашенінін. / УкрДАЗТ. - Х., 2013. - 380 с.

8 Despodov Z. Determination of reliability parameters of locomotive transport system in main haulage drift in the Toranica lead and zinc mine / Acta Montanistica Slovaca. - Ročník 3 (1998), 4. - pp. 495-498.

9 Mezitis M., Lubinskis V., Krepsha J. Research reliability realization of train schedule. / M. Mezitis, V. Lubinskis, J. Krepsha. - Transbaltica 2011. The 7th International Conference May 5-6, 2011, Vilnius, Lithuania. Selected papers. - pp. $108-111$.

10 Gandhare S.N., Madankar T.A., Ikhar D.R. ReScheduling Of Maintenance Tasks for Diesel Locomotive (ZDM) Maintenance Work Using FMEA Technique- An Industrial Engineering Approach for Saving the Resources. / OSR Journal of Mechanical and Civil Engineering (IOSR-JMCE) International Conference on Advances in Engineering \& Technology - 2014 (ICAET-2014) PP 47-54

11 Bose D., Gliosli G., Maiidal K., Sau S.P., Kuuar S. Measurement and Evaluation of Reliability, Availability and Maintainability of a Diesel Locomotive Engine. / International Journal of Scientific and Research Publications, 2013. - Volume 3, Issue 9. - pp 1-18.

12 Zhang Z, Ga o W, Zhou Y, Zhang Z. Reliability modeling and maintenance optimization of the diesel system in locomotives. Eksploatacja i Niezawodnosc Maintenance and Reliability 2012; 14 (4): 302-311.

13 Чигирик Н.Д. Класифікація складових систем експлуатації маневрових тепловозів на залізницях України. / Н.Д. Чигирик, А.Л. Сумцов, Ю.В. Білецький. / Логістичне управління та безпека руху на транспорті. Збірник тез науковопрактичної конференції. 4 - 8 травня 2015 р. м. Лозова. - Сєвєродонецьк, 2015. - с. 45 - 46.

14 Сумцов А.Л., Трубихин О.В., Брагин Н.И. Анализ показателей для определения межремонтных интервалов тепловозов // А.Л. Сумцов, О.В. Трубихин, Н.И. Брагин. / Локомотивы XXI век. Сборник материалов Международной научнотехнической конференции, посвященной 110-летию со дня рождения д.т.н., профессора Е.Я. Гаккель. - Санкт-Пертербург, 2013. - с. 109 112.

15 Положення про планово-попереджувальну систему ремонту технічного обслуговування тягового рухомого складу (електровозів, тепловозів, електро та дизель-поїздів). / Затвердженно наказом Укрзалізниці №093Ц від 30.06.2010 р. - Київ, 2011. $-30 \mathrm{c}$.

16 Тепловоз маневровый ЧМЭ-3М. Руководство по эксплуатации и техническому обслуживанию. 
ЧАСТЬ 3. Инструкция по техническому обслуживанию ЧМЭ-3М.00.03.000РЭ.

17 Тартаковский Э.Д. Методы оценки жизненного цикла тягового подвижного состава железных дорог./ Э.Д. Тартаковский, С.Г. Грищенко, Ю.Е. Калабухин, А.П. Фалендыш. - Луганск: издательство «Ноулидж», 2011. - 174 с.

Фалендыш А.П., Сумцов А.Л., Артеменко А.В. Программный комплекс выбора системы технической эксплуатации маневрового тепловоза. Рассмотрен программный комплекс выбора системы технической эксплуатации для маневровых тепловозов. В основу комплекса положена методика выбора системы технической эксплуатации тягового подвижного состава на базе определения комплексного коэффициента технической эксплуатации. Проведены расчеты для выбора системы технического обслуживания и ремонта для тепловозов ЧМЭЗ, в зависимости от основного типа работы, которая ими выполняется.

Ключевые слова: техническая эксплуатация, маневровый тепловоз, комплексный коэффициент технической эксплуатации, система ремонта.

Falendysh A.P., Sumtsov A.L., Artemenko O.V. Software complex to choose a system of shunting diesel locomotive technical maintenance. Software complex to choose a system of technical maintenance has been considered. A lot of works have been devoted to the problem of the choice of optimal system of technical maintenance (TM).

However the problem of complex estimation of diesel locomotive MS systems has not been solved to an end. The approach to the choice of technical maintenance and repairs system of a shunting locomotive on the base of determining complex coefficient of technical maintenance has been considered in the article.

For that, the analysis of publications showing the absence of a complex approach to the solution of the given task with the existing methods has been carried out. The possibility to apply different strategies of maintenance system within the frames of a general conception raises the urgency of the problem.

At that different indices characterizing only separate component parts of TM system are used as the criteria of choice. A method to determine complex coefficient of technical maintenance has been presented in the article and its modeling to choose MS of diesel locomotives ЧМЭ3 depending on the type of performed work has been conducted. Key words: technical maintenance, shunting diesel locomotive, the complex coefficient of technical maintenance, repair system.

Рецензент д.т.н., професор Жалкін Д.С. (УкрДУЗТ)
Фалендиш Анатолій Петрович, доктор технічних наук, професор, завідувач кафедри «Теплотехніка та теплові двигуни», Український державний університет залізничного транспорту, Харків, Украӥна. Номер ORCID: https://orcid.org/0000-00033602-7945

Сумцов Андрій Леонідович, асистент кафедри «Експлуатація та ремонт рухомого складу», Украйнський державний університет залізничного транспорту, Харків, Україна. Номер ORCID: https://orcid.org/0000-0002-3121-9545

Артеменко Олександр Вікторович, аспірант кафедри «Експлуатація та ремонт рухомого складу», Украӥнський державний університет залізничного транспорту, Харків, Україна. Номер ORCID: https://orcid.org/0000-0003-4881-8306

Anatoliy Falendysh, Doctor of technical sciences, professor, head of department «Thermal Engineering and Heat Engines», Ukrainian State University of Railway Transport, Kharkiv, Ukraine. Number ORCID: https://orcid.org/0000-0003-3602-7945

Andriy Sumtsov, Assistant Department «Maintenance and repair of rolling stock», Ukrainian State University of Railway Transport, Kharkiv, Ukraine. Number ORCID: https://orcid.org/0000-0002-3121-9545

Oleksandr Artemenko, PhD student, Department «Maintenance and repair of rolling stock», Ukrainian State University of Railway Transport, Kharkiv, Ukraine. Number ORCID: https://orcid.org/0000-0003-4881-8306 